\title{
Societal Engagement, Democratic Transition, and Constitutional Implementation in Malawi
}

\author{
Matteo Nicolini, Martina Trettel ${ }^{1}$
}

The People themselves must be involved in the formulation and adoption of their Constitution because ... a Constitution imposed on the people by force cannot be the basis of a stable and peaceful Government of the People.

Guidelines on Constitutional Issues, 1991, 1.

\section{The Durable Path towards Democracy in Malawi}

Over the last three decades, new winds of democratic change have been blowing over African constitutionalism (Oloka-Onyango 2001; Manga Fombad 2007; Manga Fombad and Murray 2010). These winds have stimulated the transition of several states from authoritarian rule to a democratic regime, and therefore have favoured the adoption of new constitutions in many emerging African democracies. ${ }^{2}$ The details of this assumption need not detain us here: suffice it to say that transitions also concerned the former English colonies, in general, and the Anglophone Commonwealth countries of eastern and southern Africa (ESA states), ${ }^{3}$ in particular.

The purpose of this chapter is not to assess the multifaceted features that democratisation has taken on throughout Anglophone Africa since the inception of this democratisation wave in the early 1990s. Nor will it focus on how African

\footnotetext{
${ }^{1}$ While this chapter was discussed jointly by both authors, Sections 1, 2, and 6 were written by Matteo Nicolini and Sections 3, 4, and 5 by Martina Trettel.

${ }^{2}$ For more on these new winds of change, see Slinn 1991 and Ghai 1991; Richard 1997. For Francophone Africa, see Reyntjens 1991, 44; Gaynor 2010. For Anglophone Africa, see Hatchard et al. 2010, 22-3. For a critical assessment, see Green 1989, 47. Botswana was the only country that retained a democratic constitutional context in the aftermath of decolonisation: see Cook and Sarkin 2001.

${ }^{3}$ See Hatchard et al. 2010, 2-4, and 3 note 7, where Mozambique is omitted from the ESA states because it is 'a Lusophone country with a radically different constitutional tradition' (at 3 note 7 ).
} 
countries underwent democratic transition: in-depth analyses have been already dedicated to this topic. ${ }^{4}$

Instead, it will focus on the case of Malawi, an ESA state that experienced a remarkable constitution-making process. We contend that, when drafting their constitutions, ESA states, in general, and Malawi, in particular, blazed innovative trails to democracy, thus experiencing heterogeneous processes of constitutional transition. On the one hand, leaders and political movements that promoted democratic transition resorted to constituent assemblies and constitutional commissions. On the other hand, as they were 'seeking the people's views' (Hitchard et al. 2010, 29), they adopted innovative constitution-making mechanisms. To this extent, constituent assemblies were complemented by mechanisms of both direct democracy and citizens' participation, such as commissions of inquiry or constitutional commissions that toured the countries in question to hold public meetings. ${ }^{5}$

The choice to involve the populace reveals a fallacy in the current Western narrative on Africa's transition to democracy. Instead of merely mimicking the Western legal tradition (Banda 2009), African constitutionalism proved to be innovative and far-sighted. Indeed, although American and European scholars have been examining civic and public participation since the second half of the 20th century (Kaufmann 1969; Auerbach 1972; Hart 1972), the most developed countries have been drawing on participatory mechanisms in constitution-making processes only since the first decade of the 21 st century, as the cases of Iceland, Ireland, and, at the subnational level, Canada and Italy, show (Tushnet 2014, 19ff; Suteu 2015; Trettel 2015).

This blazing of innovative trails towards constitutional democracy allows us to propose an alternative reading of African constitutionalism. Societal inclusion in

\footnotetext{
${ }^{4}$ See Huntington 1991. Although scholars mainly focus on South Africa (Sachs 1991; Wing 2000; Asmal 2007), all ESA states - with the major exception of Zimbabwe - have experienced a transition to democracy, including Kenya, Lesotho, Malawi, Tanzania, and Zambia. See Hatchard et al. 2010, 22 and 28ff. This is apparent as regards Namibia: see Cottrell 1991 and the seminal judgment in $S v$ Van Wyk 1992(1) SACR 147 (Nm. SC), at 172-173: 'Throughout the preamble and $[\ldots]$ the Namibian Constitution there is one golden and unbroken thread - an abiding 'revulsion' of racism and apartheid [...] I know of no other Constitution in the world which seeks to identify a legal ethos against apartheid with greater vigour and intensity.'

${ }^{5}$ For a comprehensive overview, see Hitchard et al. 2010, $29 \mathrm{ff}$.
} 
constitution-making processes has proven to render durable the transition to democracy and therefore the new constitutional designs that have been developed: since the early $1990 \mathrm{~s}$, legacies of transition have continued to shape African constitutionalism. Such durability is apparent when we consider how 'most of the post-1990 [...] African constitutions attempt [...] to place some limits and restrictions on the powers of governments to amend the constitution' (Manga Fombad 2013, 383). Legacies of the democratic shift are still present, as the numerous new democratic constitutions, recently approved in Kenya (2010), Zimbabwe (2013), and Zambia (2016), demonstrate (Stacey 2010; Chizuda 2014). Finally, durability has also been embedded in democratic constitutions, and societal engagement now governs the implementation of these durable constitutions.

This also holds true for Malawi, a small developing country in southern Africa, bordered by Mozambique, Tanzania, and Zambia (Patel et al. 2007, 2-4). On the one hand, public participation complemented the work of the 1994 constituent assembly; on the other hand, the 1995 Constitution explicitly refers to societal participation in decision-making processes, in general, and in the implementation of governmental activities, in particular. There are indeed several participatory mechanisms that allow civil society to engage in parliamentary activities, including 'advocacy and direct lobbying, developing position papers [...] civic education and networking' (Hussein 2005, 88-90). In this respect, participation pervades the entire spectrum of constitutionally entrenched decision-making processes, and represents a strong critical voice that has proven to be a contrast to attempts, in the last two decades, to turn Malawi into an authoritarian democracy.

\section{Setting the Scene: The Colonial Legacy and Malawi's Participatory Spirit}

In order to shed light on the role of public participation in both Malawi's democratic transition and constitutional implementation, we will first provide a brief overview of the socio-economic, historical, and political scenario that characterises this southern African country. ${ }^{6}$

\footnotetext{
${ }^{6}$ On Malawi’s constitutional development, see Kapindu 2014.
} 
With about 15 million inhabitants, Malawi is one of the world's poorest countries, and with more than half its population living in poverty, Malawi 'has ranked consistently as one of world's least developed countries and relies heavily on concessionary development aid' and donations coming from foreign countries, especially the United States and the United Kingdom (Scholz 2008, 1). Thus, Malawi is a 'small heavily donor-dependent nation [...] subject to the preferences of donors' (Anderson 2013, 1).

This is apparent throughout Malawi's constitutional history. On the one hand, Malawi tried to sever its relations with its former colonial rulers. As soon as it gained independence from the United Kingdom in 1964 (on the colonial period, see Rotberg 1965), it promptly relinquished the Westminster model. The Queen, who originally remained as head of state represented by a governor-general under the 1964 Constitution (see Section 28: Roberts 1964), was replaced in 1966 by an elected president. On the other hand, colonial legacies contributed to rendering Malawi a closed society, which indeed had its roots in the English Protectorate of Nyasaland (1891-1961) ${ }^{7}$ and in the Constitution of the Federation of Rhodesia and Nyasaland in 1953.

Third, this closed society was secured by the authoritarian dictatorship of Hastings Kamuzu Banda, which lasted more than 30 years (1961-1993) until 1994, i.e., when the country moved in the direction of multi-party democracy (Chirwa 2014, 3). Indeed, from 1961 to 1993, Banda presided over Malawi's one-party state, which was characterised by autocratic and oppressive rule. This, however, did not prevent the regime from adopting an authoritarian Constitution in 1966. According to Section 4 of the 1966 Constitution, the Malawi Congress Party (MCP) was the only legally acknowledged political movement in the country, and Section 9 declared Banda president for life (Kanyongolo 2012, 3; Mwiza 2016). Moreover, Section 2(1) codified unity, loyalty, obedience and discipline, and party slogans as the four cornerstones of the government and the nation (Chimimba 2012, 40)

Fourth, donors also contributed to the preservation of Malawi's closed society: because of Banda's anti-communist politics, the regime benefited from strong

\footnotetext{
${ }^{7}$ See Africa Order-in-Council 1889, followed by the British Central Africa Order-in-Council 1902 (as amended in 1907 and 1912). See Chimimba 2012, 23 notes 19 and 26.
} 
support among Western powers. As a consequence, 'Malawi was the only African state which maintained full and cordial diplomatic relations with the apartheid government of South Africa' (Patel et al. 2007, 7).

The authoritarian regime lasted for about 30 years until the 'winds of change began to blow across the globe, also engulfing the continent, and change became imminent' in Southern Africa (Patel et al. 2007, 7).

This means that Malawi's closed society started opening up and experiencing democratic participation after the end of the Cold War and the collapse of the Soviet Union in the late 1980s. Again, international donors triggered the path towards an open society. Various domestic and international actors exerted pressure on the authoritarian regime in order to open up Malawi's closed sociopolitical context. ${ }^{8}$ Banda's authoritarian government thus agreed to hold a national referendum in order to directly involve the population in the decision regarding what kind of political structure Malawi would adopt.

This referendum may undoubtedly be considered the starting point for comprehensive reflection on societal participation in Malawi's constitutional democratic rule. In fact, direct democracy represented the first stage of the whole constitution-making process, through which Malawi also devised its own constitutional conception of popular participation. Societal involvement must then 'take into account the concerns of the widest possible segment of the population, must be transparent in its work, and to make such consultations meaningful, must properly structure its methods of consultation' (Hitchard et al. 2009, 34).

This is what we call 'participatory spirit': not only does it still pervade Malawi's Constitution, but it has also played a role in contrasting shifts towards authoritarianism. In fact, several constitutional amendments passed between 2000 and 2004 were aimed at subverting Malawi's constitutional democracy and therefore at satisfying 'the personal short-term interests of those wielding

\footnotetext{
${ }^{8}$ See Patel et al. 2007, 7-8, which provides examples of events and actors pushing for the democratic transition. Among them, we can mention the 1992 pastoral letter issued by eight Catholic bishops against the regime, worker demonstrations and riots, the return from exile of opposition and trade union leader Chakufwa Chihana, and the creation of new political groups. As for external pressure, in 1992 the World Bank Consultative Group 'froze all aid to Malawi, citing the Banda government's poor human rights record and widespread political repression'. See Meinhardt 2001, 223ff; Chikaya-Banda 2012, 9.
} 
governmental powers'. ${ }^{9}$ Nonetheless, '[t] hese and similar moves prompted civil society to keep a close watch on the government, making it more a watchdog than a partner in the governance process' (Patel et al. 2007, 20).

When devising the evolution of public participation in Malawi, we thus cannot limit our study to the period of the constituent process. We also have to take into account how public participation has evolved in the last 20 years of democratic rule. First, the voices of citizens have been heard through many channels during the development of a democratic Malawi. Second, participation adopted both an institutional (i.e., top-down) approach, as well as a bottom-up perspective. ${ }^{10}$ In this regard, with its 23 chapters and 214 sections, the Constitution covers every conceivable area of Malawi's economic, political, and social life (Mutharika 1996, 205), as well as public participation. On the one hand, Section 40(1)(c) explicitly states that every person must have the right 'to participate in peaceful political activity intended to influence the composition and policies of the Government'. On the other hand, Section 146(2)(c) does the same with regard to local government, which has the responsibility for 'the consolidation and promotion of local democratic institutions and democratic participation'.

\section{Popular Participation in the Constitution-Making Process (1994-1995)}

We have already referred to the external and domestic actors that promoted Malawi's transition to democracy. In this respect, both international donors and a popular movement acted as variables pushing for the introduction of a new democratic design, and therefore led to seeking the people's views through the means of direct democracy. Hence, a referendum was held in 1993, and voters were asked to choose whether they preferred Malawi to remain a one-party state or to become a multi-party democracy.

\footnotetext{
${ }^{9}$ Patel et al. (2007, 19-20) highlight how these amendments included the repeal of the section on the Senate, the amendment to Section 65 dealing with floor-crossing by members of parliament, and the attempt to extend the presidential term of office.

10 Both features usually complement analyses of Malawi's evolution towards constitutional, participatory democracy. For an assessment of popular participation from an institutional perspective, see Chirwa 2014. On the bottom-up approach, see Chihana 2008.
} 
Although 'President Banda was confident that Malawians would vote to retain the status quo - a one party system with him as head of state' (Chiyaka-Banda 2012, 9; see also Mwiza 2013), the referendum demonstrated Malawi's mature democratic and participatory spirit. The referendum saw a very high degree of voter participation, in African terms, with a 69 per cent turnout. About 67 per cent of all those who voted chose multi-party democracy, while 33 per cent were in favour of preserving a one-party system (Dzimbiri 1994).

The constitution-making process started at the beginning of 1994, right after the referendum was held. The National Assembly eventually passed the provisional constitutional provision for the Republic of Malawi (Constitution), Act No. 20 of 1994. However, the pivotal decision to transform Malawi into a plural-democratic system was complemented by a traditional constitution-making process, as the constitutional assembly acted without any proper and broad-based societal consultation.

If popular participation in constitution-making is the legitimate legal source upon which a democratic state is built, in the Malawian experience, the lack of consultation diminished the democratic legitimacy of the Constitution.

In this regard, the responsibility for drafting the new constitution was entrusted to a National Consultative Council (NCC), which was established by the National Consultative Council Act No. 20 of 1993 (Chimiba 2012, 47). However, 'none of [its] members [...] were such by virtue of any popular elections; they did not have any direct mandate from the people to determine even the most basic framework of the Constitution' (Hara 2007).

Furthermore, there was a "significant influence of the "international experts" in the drafting process [...] of the Constitution' and '[s]ome of the recommendations of the international experts seem to reflect the Western Donors' views of the Constitution to be created' (Hara 2007). In addition, the NCC delegated the constitution-making process to a team of five Malawian experts with a British lawyer acting as an advisor (Chikaya-Banda 2012, 9; Kanyongolo 2012, 7; Mwiza 2013, 234). 
It should also be noted that the NCC started drafting the constitutional text at a time when many other activities were taking place, especially the organisation of the first general and democratic elections after 30 years of authoritarian rule.

The lack of democratic legitimacy, however, did not affect Malawi's democratic spirit. In this regard, it should be noted that the 1994 Constitution was an interim constitution that was to enter into force only for a one-year provisional period. In fact, Section 212 of the 1994 Constitution provided for the review of the Constitution during its provisional application by foreseeing the three following activities:

(a) national civic education and consultation, during which the Committee would be involved in matters of public awareness and consultation on the Constitution; (b) the holding of a national conference 'fully representative of Malawian society'; and (c) the consideration of the constitutional proposals by the National Assembly (Chimiba 2012, 50).

The National Assembly (Malawi's legislative body) appointed an internal Parliamentary Constitutional Committee, which was entrusted with the examination of the interim Constitution in order to propose amendments that could make it a permanent constitutional text. The Committee was also charged with the organisation of a popular consultation (the so-called Constitutional Review Conference): via public participation, citizens and representatives of all segments of Malawian society were thus given an opportunity to propose constitutional amendments. The Committee conducted hearings in the 24 administrative districts of Malawi, and every citizen could attend and make proposals. A national constitutional conference was then organised in February 1995: it was attended by 274 delegates from political parties and civil society organisations and lasted five days (Hara 2007).

Despite the efforts to involve the populace in the revision process, the Conference was considered inadequate: it was capable neither of exerting a real influence on the drafting of the permanent Constitution nor did it create a strong link with the 
population. ${ }^{11}$ This is apparent if only we consider that, when Parliament voted on the final constitutional text, it disregarded the two recommendations explicitly framed during the Conference: one regarded 'the suspension of a provision for a senate', and the other 'the repeal of the recall provision' (Chikaya-Banda 2012, $10)$.

Even in the absence of tangible popular involvement in the process, the permanent Constitution became the Constitution of Malawi Act No. 7 of 1995, which was passed by the National Assembly on 11 May 1995 and assented to by the President on 17 May 1995.

\section{What Is the Best Form of Participation for Malawi's Constitutional}

\section{Democracy? From Elections to the Law Commission}

Even if popular involvement was relatively scarce throughout the constituent process, since 1993 Malawians have had the possibility to take part in parliamentary and presidential elections, and therefore to democratically express their will.

It should be noted that the concept of participation takes different forms and often serves different functions according to both the constitutional context and the subject matter it applies to. When applied to mature democracies, ${ }^{12}$ citizen participation usually encompasses a decision-making process that goes beyond representative democracy. As the latter is currently undergoing a profound structural crisis, Western countries usually complement representative institutions with democratic participation, i.e., with mechanisms that enable citizens to be directly involved in policy-making processes (Ank 2009; Sintomer et al., 2012). However, it is indisputable that, in modern and contemporary constitutional history, the concept of participation has always been theoretically related to representative democracy, to which, in more recent times, it has added elements carved out from deliberative and direct democracy (Frankenberg 2012). The

\footnotetext{
${ }^{11}$ Indeed, two years later, 'few people reportedly had "any idea what a constitution is"'. See Brown 2008. See also Mwiza 2013, 236.

${ }^{12}$ Mature democracies encompass those legal systems in which constitutions are fully developed, operational, and guaranteed. See Dahl 1992.
} 
representative character of the liberal democratic system thus influences the same degree of institutional innovation. This holds true as far as participatory and deliberative democracies are concerned. Under constitutional democracy, liberal democracy governs the relations between different kinds of democracy (Wampler 2008, 70). Representative democracy is related to deliberative democracy, which presupposes a model in which deliberation, through argumentation and persuasion, gives way to the broadest consent possible in public decisions. Evidently, when applied to representative democracy, deliberation aims to establish qualified majorities, not only in constitutional legislation or reform but also in the basic laws of local autonomies (Nicolini 2015, 440).

This also holds true when we apply the concept of participation to emerging democracies: indeed, the concept in question allows us to examine their institutional developments from a very broad constitutional perspective that includes direct, deliberative, and representative mechanisms of public participation.

These theoretical reflections also match Malawi's empirical experience, where political participation through free and equal elections has contributed to the development of the democratic features of the new institutional system. Furthermore, the interrelations between the concept of participation and representation are particularly apparent in Malawi: indeed, '[a]lternative definitions and forms of democracy were not discussed in Malawi, and a liberal democracy with the principle of separation of powers with adequate checks and balances among the three arms of government was thus the essence of the constitution making [process]' (Patel et al. 2007, 9). Together with the popular commitment to democracy, the trust placed in the traditional democratic decisionmaking process is empirically demonstrated by the extremely high turnout in the 1994 and 1999 elections, which reached 80 per cent and 94 per cent, respectively (Wiseman 2014, 4).

Electoral participation, which played and still plays a pivotal role in the development of Malawi's constitutional democracy, is complemented by additional channels of popular involvement, which support a viable and durable democratic evolution of Malawi's institutional context. 
We refer to the activity of the Law Commission, as it is laid down in Section 135 of the Constitution, which reviews Malawi's laws in order to ensure that they comply with constitutional and international law. On the one hand, this independent body was conceived of as a means for guaranteeing the coherence of the legal system by amending and removing all pieces of legislation that were inconsistent with the democratic constitutional provisions. ${ }^{13}$ On the other hand, it has the power to review and make recommendations regarding any matter pertaining to the Constitution: to this extent, and pursuant to these powers, two public conferences were organised in 2006 and 2007.

However, the Constitution does not establish a clear methodology for the functioning of the Law Commission: it was the same members of the Commission who ultimately outlined it. As stated by Chikaya-Banda, a former member of the Law Commission:

The Law Commission receives submissions calling for changes in the law from individual and institutional sources both private and public [...] Submissions are assigned to law reform officers. They then conduct research to identify potential problem areas with the topic. These are set out in an 'issue paper' which announces the inception and scope of the review (Chikaya-Banda, 2012, 11).

In order to strengthen citizen participation, the Commission decided to establish special and provisional Law Committees, which were entrusted with reviewing legislation related to specific and technical topics. We can detect a strong participatory feature in the approach to the Committees, as their composition included representatives of different segments and the interests of civil society. Commissioners could indeed be professionals, such as judges and lawyers, traditional leaders, or members of associations and organisations (Chikaya-Banda $2012,11)$

Since its establishment in 1998, public stakeholders have engaged the Law Commission in order to undertake a comprehensive review of the Constitution.

13 For more information regarding the Law Commission and its composition, see http://www.sdnp.org.mw/lawcom/index.htm?http\%3A//www.sdnp.org.mw/lawcom/personnel.htm (accessed 14 May 2016). 
The Commission was persuaded that such a review had to rely on broad popular engagement, contrary to what happened in the process of the adoption of the 1995 Constitution. Therefore, the Commission decided in 2004 to establish a nationwide, highly publicised consultation that would last one year and take place through specific focus groups, discussions with traditional authorities, and informal consultation panels (Chikaya-Banda 2012, 16).

Finally, it should be observed that Malawi's Constitution has been amended many times, thus showing its profound weakness and lack of internal guarantees. These changes have been of various kinds, from very narrow to very broad amendments. The most extensive changes occurred in 1995, 1997, 1998, 1999, 2001, and 2010 (Wiseman 2014, 5).

\section{Spreading the Participatory Spirit in Malawi: Public Access to} Policymaking and Local Government

The participatory spirit enshrined in the Constitution pervades not only constitutional and law-making processes, it also shapes governmental action: (a) civil society organisations may be granted a permanent seat on the governing boards of state institutions or parastatal organisations; (b) the executive may allow non-governmental organisations to take part in the development of public policies; (c) the executive has embraced a participatory approach to budget-making procedures. During budget-making sessions, the Minister of Finance organises workshops and breakfast meetings on a merely consultative basis: civil society organisations, universities, and the private sector are thus involved in the budgetary process (Wiseman 2014, 9). ${ }^{14}$

Furthermore, citizens participate in the design and implementation of state legislation and public policies at the local level. Pursuant to Sections 3 and 6(1)(b) of the Local Government Act 1998, local government must promote the participation of the people in decision-making processes and consolidate local democratic institutions and participation (See Patel et al. 2007, 61ff.). Indeed, a high degree of subnational and local decentralisation offers 'many opportunities to

\footnotetext{
14 This approach to the budget-making process is akin to participatory budgeting. See Sintomer et al. 2012; Wampler 2012. For a broad comparative overview, see Dias 2012.
} 
look for new ways of increasing citizen participation' (Sommermann 2015). In Malawi, the decentralisation process has been very weak because of the absence of a clear political project regarding local entities and the failure to hold local elections that should have taken place the year after the general elections (1994). ${ }^{15}$ Only in 1998 was the Government of Malawi able to pass a law on local government (the above-mentioned Local Government Act 1998) and to establish local entities and approve the National Decentralisation Policy (NDP). Thereafter, local elections were finally held in 2000 , though with a very low turnout of only 14 per cent.

The pendulum swung back towards recentralisation in 2005. As local government mandates came to an end, assemblies were dissolved and eventually suspended. The details of the suspension of Malawi's local government need not detain us here; suffice it to say that, while framing a new NDP, the executive identified in the lack of popular awareness and local participation one possible reason for this political failure (Chihana 2008, 61).

However, budgetary and political issues regarding the further development of local government structures remained unresolved, and local elections were postponed until 2014, when the presidential, parliamentary, and local elections were all held simultaneously for the first time in the country's history (Patel and Wahman 2015, 80). In order to support the development of a stronger local level of government, a pilot participatory experience was established in February 2006 in three Malawian districts. This was implemented through the method of open space technology, a participatory approach invented by Harrison Owen in 1992 (Owen 2008) that examines how civil society should contribute in the development of local districts. The experiment had a positive effect and showed that it would be possible to strengthen local government by opening up space for citizens to be directly involved in policymaking processes. This methodology in fact increases the legitimacy of representative institutions, which comply with their legislative and executive decisions (Chihana 2008, 61).

\footnotetext{
${ }^{15}$ On local government, see Section 146(2) of the Constitution.
} 


\section{Does the Participatory Spirit Really Work? The Light and the Shadow of}

\section{Malawi's Democratic Constitutional Framework}

Unlike other African countries, Malawi resolved the political, ethnic, and religious conflicts that arose during its transition towards democracy through institutional solutions instead of resorting to violent armed conflicts. This was possible because the participatory spirit enshrined in the 1995 Constitution helped in developing Malawi's democratic governmental framework.

To this extent, the Constitution was aimed at promoting and safeguarding multiparty democracy, separation of powers, as well as the civil, political, and social rights of all Malawians (Chikaya-Banda 2012, 6). However, it has been argued that, using Roscoe Pound's legal taxonomies, Malawi's Constitution has probably remained more 'law in books' rather than becoming 'law in action': the failure of the Constitution 'to facilitate democracy and development is attributed mainly to dysfunctions in its interpretation, application and enforcement, and not to its fundamental premises' (Kanyongolo 2012, 2).

Whereas the fundamental principles and rules foreseen in the Constitution grant Malawi the basis for establishing a real multi-party democracy, as well as civic and political participation, the subsequent evolution of the political, economic, and social reality has led to a misuse of the constitutional rules, as the saga of the approval of several amendments and of the suspension of local government clearly demonstrates.

From this, however, it does not follow that no lessons can be drawn from how Malawi articulated public participation. If we compare Malawi to many other African countries, we can positively evaluate the role played by the participatory spirit entrenched in the Constitution. As already mentioned, this spirit helped avoid violent conflicts during the transition to democracy. In addition, it ensured broad public participation in the constitution-making process and allowed the populace to take part in the implementation of the Constitution, in general, and in legislative and governmental policymaking processes and actions, in particular. In other words, 'the [c]ountry has a popularly accepted constitution that enjoys broad-based legitimacy, established institutions for democratic governance and 
adequate mechanisms and opportunities for the promotion of popular participation in politics' (Wiseman 2014, 30).

This is not to deny the frequent problems that affect the transition to democracy and the establishment of constitutional democracy in Malawi. The high levels of aid dependency and indebtedness, the conditional use of donors' funds, the high degree of corruption in politics, the absence of strong guarantees ensuring the application of the Constitution, and the failure of the decentralisation process made it possible to challenge and progressively reduce the room left for popular participation.

Thus, tensions and contradictions remain. On the one hand, there is the blackletter Constitution with its provisions regarding democracy, civil and social rights, citizenship and participation; on the other hand, there are political and cultural legacies, such as the role of traditional chiefs, who have a strong impact on the implementation of constitutional provisions. Indeed, public participation must cope with the strong powers that are traditionally vested in the chiefs (Gaynor 2010, 803; Chihana 2008, 59) without divorcing the principles of democracy and good governance from African customary traditions (Tambulasi and Kayuni 2005, $158)$.

As public participation exhibits a great deal of resilience, it will probably be capable of amalgamating the two different, albeit intertwined, features exhibited by Malawian societal engagement: the participatory one, which focuses on people's involvement in decision-making processes, and the traditional one, which rests on tribal and communitarian networks. This objective, however, was already laid down in the Local Government Act 1998. Indeed, Section 5(1)(b) of the Act recognises 'Traditional Authorities and Sub-Traditional Authorities [...] as non-voting members ex-officio of local assemblies'; at the same time, section 3 assigns to local assemblies the responsibility for consolidating and promoting local democratic institutions.

Hence, the participatory spirit may conjugate both sides of Malawian societal context (that resting on engagement and that relying on traditional law). If it is the case, this will mean that the flaws between the black-letter constitution and the 
living one have been overtaken and that the time for a strong constitutional democratic commitment in Malawi has come.

References

Anderson, N. (2016). 'Ephemeral Development Agendas and the Process of Priority Shifts in Malawi', Journal of Asian and African Studies, 51(1), 1-17.

Ank, M. (2011). 'Innovations in democratic governance: how does citizen participation contribute to a better democracy?', International Review of Administrative Sciences, 77(2), 275-293.

Asmal, K. (2007). 'The South African Constitution and the Transition from Apartheid: Legislating the Reconciliation of Rights in a Multi-Cultural Society', European Journal of Law Reform, 9(2), 155-166.

Auerbach, C.A. (1972). 'Pluralism and the Administrative Process', Annals of the American Academy of Political and Social Science, 400, 1-13.

Banda, S. (2009). 'Constitutional Mimicry and Common Law Reform in a RightsBased Post-Colonial Setting: The Case of South Africa and Malawi', Journal of African Law, 53(1), 142-170.

Brown, S. (2008). 'The Transition from a Personal Dictatorship: Democratization and the Legacy of the Past in Malawi', in W. N. Shadrack (ed.), The African Search for Stable Forms of Statehood: Essays in Political Criticism, Edwin Mellen Press, Lewiston, 2008, 187-227.

Chihana, P. (2008), 'Opening space for participation in Malawi', in P. Chihana et al. (eds.), Towards the Consolidation of Malawi's Democracy: Essays in honour of the work of Albert Gisy German Ambassador in Malawi (February 2005-June 
2008), Konrad Adenauer Stiftung, Sankt Augustin, Occasional Paper No. 11, 57 67.

Chikaya-Banda, J. (2012). 'Constitutional and law reform in Malawi', Policy voices series - Africa Research Institute, 1-20.

Chimimba, T. P. C. (2012). 'The Search for Identity and Legitimacy: the Evolution of Malawi's Constitution', Malawi Law Journal, 6(1), 19-62.

Chizuda, L. (2014). 'Towards the protection of human rights: do the new Zimbabwean constitutional provisions on judicial independence suffice?', Potchefstroom Electronic Law Journal, 17(1), 367-417.

Cook, A. and Sarkin, J. (2010). 'Is Botswana the Miracle of Africa? Democracy, the Rule of Law, and Human Rights Versus Economic Development', Transnational Law \& Contemporary Problems, 19(2), 453-489.

Cottrell, J. (1991). 'The Constitution of Namibia: An Overview', Journal of African Law, 35(1-2), 56-78.

Dahl, R. (1992). 'Democracy and Human Rights under Different Conditions of Development', in E. Asbjørn and H. Bernt (eds.), Human Rights in Perspective, Blackwell, Oxford, 235-252.

Dias, N. (ed.) (2014). Hope for democracy: 25 years of participatory budgeting worldwide, In loco association, Sao Bras de Alportel.

Dzimbiri, L. (1994). 'The Malawi referendum of June 1993', Electoral Studies, 13(3), 229-234. 
Frankenberg, G. (2012). 'Democracy', in M. Rosenfeld and A. Sajó (eds.), The Oxford Handbook of Comparative Constitutional Law, Oxford University Press, Oxford, 250-264.

Gaynor, N. (2010). 'Between Citizenship and Clientship: The Politics of Participatory Governance in Malawi', Journal of Southern African Studies, 36(4), 801-816.

Ghai, Y. (1991). 'The Role of Law in the Transition of Societies: The African Experience', Journal of African Law, 35(1/2), 8-20.

Green, R. H. (1989). 'Participatory Pluralism and Pervasive Poverty: Some Reflections', Third World Legal Studies, 8(2), 21-56.

Hara, M. H. (2007). 'Popular Involvement in Constitution-Mmaking: the Experience of Malawi', paper presented at the World Congress of Constitutional Law, Athens, 11-15 June 2007, 15-16 (https://anayasa.tbmm.gov.tr/docs/Paperby-Mabvuto-Herbert-Hara.pdf), accessed on 6 June 2016.

Hart, D. K. (1972). 'Theories of Government Related to Decentralization and Citizen Participation', Public Administration Review, 32, 603-621.

Hatchard, J. et al. (2010), Comparative Constitutionalism and Good Governance in the Commonwealth: An Eastern and Southern African Perspective, Cambridge University Press, Cambridge, 2010.

Huntington, S. (1991). The Third Wave: Democratization in the Late Twentieth Century, University of Oklahoma Press, Norman, 1991.

Hussein, M. K. (2005). 'Malawi', South African Journal of International Affairs, 12(1), 77-93. 
Kanyongolo, F. E. (2012). 'Law, Power and the Limits of Liberal Democratic Constitutionalism in Malawi', Malawi Law Journal, 6(1), 1 1-18.

Kapindu, R. E. (2014). Malawi: Legal System and Research Resources, (http://www.nyulawglobal.org/globalex/Malawil.html), accessed 19 May 2016.

Kaufman, H. (1969). 'Administrative Decentralization and Political Power', Public Administration Review, 29(1), 3-15.

Manga Fombad, C. (2007). 'Challenges to Constitutionalism and Constitutional Rights in Africa and the Enabling Role of Political Parties: Lessons and Perspectives from Southern Africa', The American Journal of Comparative Law, $55(1), 1-45$.

Manga Fombad, C., and Murray, C. (eds.) (2010). Fostering Constitutionalism in Africa, Pulp, Pretoria, 2010.

Manga Fombad, C. (2013). 'Some perspectives on durability and change under modern African constitutions', International Journal of Constitutional Law, 11(2), 382-413.

Meinhardt, H. (2001). 'How It Began: External Actors in the Early Phase of the Democratic Transition in Malawi', Verfassung und Recht in Übersee / Law and Politics in Africa, Asia and Latin America, 34(2), 220-240.

Mutharika, P. (1996). 'The 1995 Democratic Constitution of Malawi', Journal of African Law, 40(2), 205-220.

Mwiza, J. N. (2013). 'Popular Involvement and Constitution-Making: the Struggle towards Constitutionalism in Malawi', in M. M. Kiwinda and T. Ojienda (eds.), Constitutionalism and Democratic Governance in Africa: Contemporary 
Perspectives from Sub-Saharan Africa, Pretoria University Law Press, Pretoria, 219-243.

Mwiza, J. N. (2016). The Republic of Malawi Country Report, Oxford Constitutions of the World Country Reports, (http://www.icla.up.ac.za/oxfordconstitutions/country-reports), accessed 5 May 2016.

Nicolini, M. (2015). 'Theoretical Framework and Constitutional Implications: Participatory Democracy as Decision-Making in Multilayered Italy', in F. Palermo and E. Alber (eds.). Federalism as Decision-Making: Changes in Structures, Procedures and Policies, Brill Publishing House, Leiden/Boston, 428447.

Oloka-Onyango, J. (2001). Constitutionalism in Africa: Creating Opportunities, Facing Challenges, Fountain Publishers, Kampala, 2001.

Owen, H. (2008), Open Space Technology: A User's Guide, Berrett-Koehler Publishers, San Francisco.

Patel, N. (2007). Consolidating Democratic Governance in Southern Africa: Malawi, EISA Research Report No. 33, EISA, Johannesburg.

Patel, N. and Wahaman, M. (2015). 'The presidential, parliamentary and local elections in Malawi. May 2014', Africa Spectrum, 50(1), 79-92.

Pound, R. (1910). 'Law in Books and Law in Action', American Law Review, 44, $12-15$.

Reyntjens, (1991). 'The Winds of Change. Political and Constitutional Evolution in Francophone Africa, 1990-1991', Journal of African Law, 35 (1/2), 44-55. 
Richard, J. (1997). 'Democratization in Africa after 1989: Comparative and Theoretical Perspectives', Comparative Politics, 29(3), 363-382.

Rotberg, R. I. (1965). The Rise of Nationalism in Central Africa: The Making of Malawi and Zambia, 1873-1964, Harvard University Press, Cambridge, MA.

Roberts, S. (1964). 'The Constitution of Malawi, 1964', Journal of African Law, $8(3), 178-184$.

Sachs, A. (1991). 'Towards a Bill of Rights for a Democratic South Africa', Journal of African Law, 35(1/2), 21-4.

Scholz, I. (2008). 'Introduction: Malawi's Development Course on a Knife's Edge - Do Politicians Care?', in P. Chihana et al. (eds.), Towards the Consolidation of Malawi's Democracy: Essays in honour of the work of Albert Gisy German Ambassador in Malawi (February 2005-June 2008), Konrad Adenauer Stiftung, Sankt Augustin, Occasional Paper No. 11, 1-5.

Sintomer, Y. et al. (2012). 'Transnational Models of Citizen Participation: The Case of Participatory Budgeting', Journal of Public Deliberation, 8(2), Article 9.

Slinn, P. (1991). 'A Fresh Start for Africa? New African Constitutional Perspectives for the 1990s', Journal of African Law, 35(1/2), 1-7.

Sommermann, K.-P. (2015), 'Citizen Participation in Multi-Level Democracies: An Introduction', in C. Fraenkel-Haeberle et al. (eds.), Citizen Participation in Multi-level Democracies, Brill Publishing House, Leiden/Boston, 1-12.

Smith, G. (2009). Democratic Innovations: Designing Institutions for Citizen Participation, Cambridge University Press, Cambridge. 
Stacey, R. (2011). 'Constituent power and Carl Schmitt's theory of constitution in Kenya's constitution-making process', International of Journal of Constitutional Law, 9(3-4), 587-614.

Suteu, S. (2015). 'Constitutional Conventions in the Digital Era: Lessons from Iceland and Ireland', Boston College International and Comparative Law Review, $3(2), 251-276$.

Trettel, M. (2015). 'The politics of deliberative democracy: A comparative survey of the "law in action" of citizen participation', Revista de derecho politico, 94, 85114.

Tushnet, M. (2014). Advanced Introduction to Comparative Constitutional Law, Edward Elgar Publishing, Cheltenham-Northampton.

Uganda Constitutional Commission (1991). Guidelines on Constitutional Issues, The Commission, Kampala.

Wampler, B. (2008). 'When Does Participatory Democracy Deepen the Quality of Democracy? Lessons from Brazil', Comparative Politics, 41, 61-81.

Wampler, B. and Hartz-Karp, J. (2012). 'Participatory Budgeting: Diffusion and Outcomes across the World', Journal of Public Deliberation, 8(2), Article 13.

Wing, A. K. (2000). 'The South African Transition to Democratic Rule: Lessons for International and Comparative Law', Proceedings of the Annual Meeting (American Society of International Law), 94, 254-259.

Wiseman, C. C. (2014). Malawi: Democracy and Political Participation. A review by AfriMAP and the Open Society for Southern Africa, Open Society Foundations, New York. 